\title{
Un pioner en la innovació educativa amb educomunicació audiovisual. Josep Arbiol i el seu viatge des de les aules d’Educació Primària als Festivals Internacionals
}

Per Rosa Isusi-Fagoaga ${ }^{1}$

Text elaborat sobre una entrevista realitzada al CEFIRE de València, el 11 de novembre de 2018

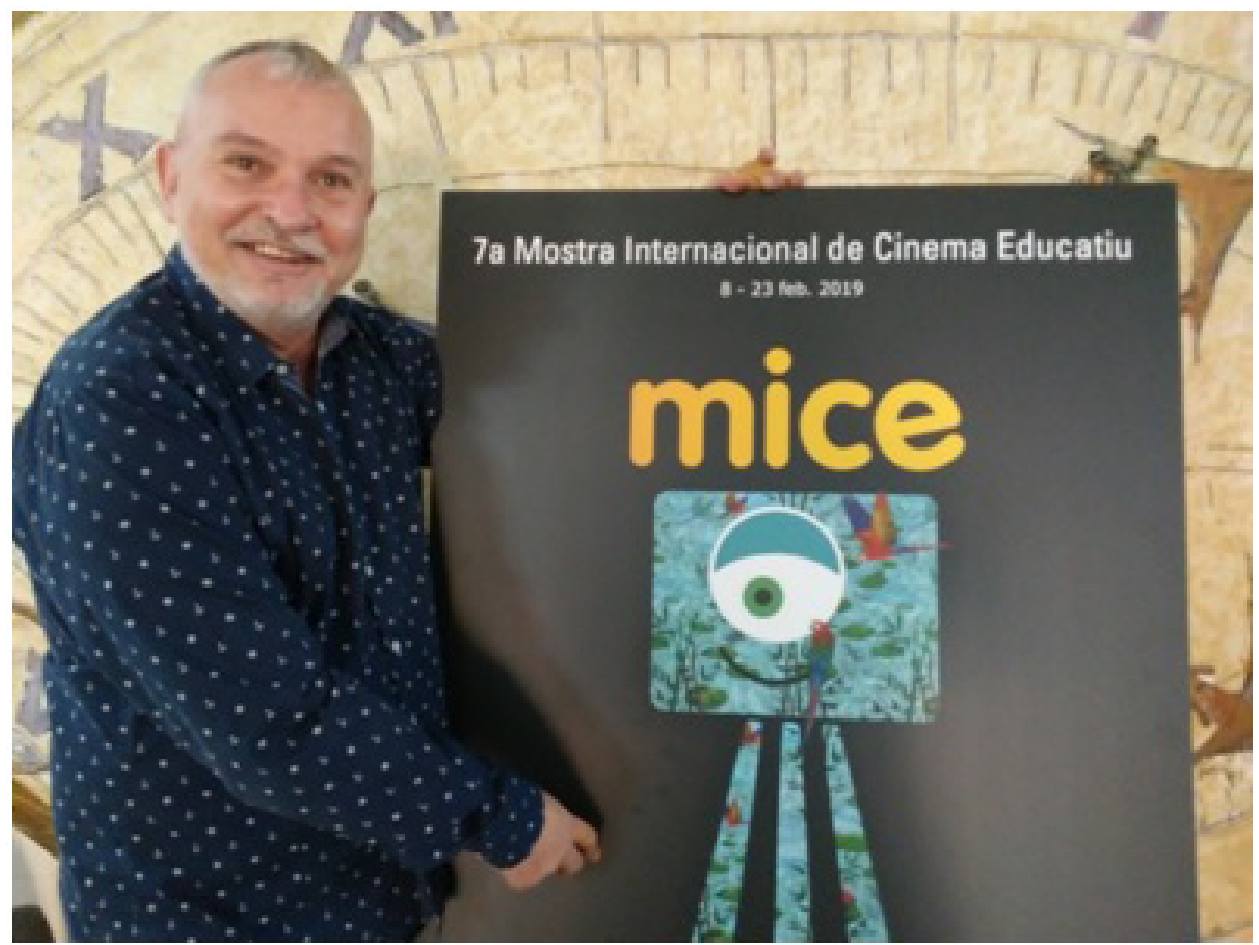

Fig. 1. Fotografia de Josep Arbiol Carmen al CEFIRE de València.

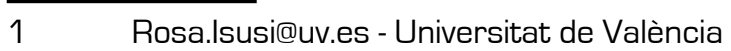




\section{Qui és Josep Arbiol Carmen? [Fig. 1.]}

Va nàixer a Estivella [València] en 1962 i és va titolat en Magisteri llicenciat en Filologia Hispànica per la Universitat de València. Amb 35anys d'experiència docent ha treballat més de vint-i-cinc anys a diverses escoles d'Educació Primària a València, especialment al Col.legi Públic Santa Teresa del emblemàtic barri d' El Carme i al CEIP Cristóbal Colon de Benetússer on ell ha desenvolupat diversos projectes educatius innovadors de gran repercussió mediàtica i social.

Té una llarga trajectòria en mitjans audiovisuals tant a Espanya com a l'estranger. El seu treball en activitats artístiques $\mathrm{i}$ pel-lícules educatives amb xiquets ha estat premiat en nombrosos festivals i concursos nacionals i internacionals [Grècia, Romania, Índia, Hongria, Bolívia, Croàcia, Itàlia, Argentina, Índia i Corea del Sud, entre d'altres]. El principal objectiu del seu treball és proporcionar més canals per a la creativitat dels joves, tractant d'aconseguir l'èxit que els porta a desenvolupar la seua pròpia creativitat sense copiar altres formes. Ha impartit conferències i participat en taules rodones a Espanya i internacionalment (Mèxic, Índia, Sèrbia, Taiwan, Corea, Itàlia, Grècia, Hongria, Cuba i Txèquia] així com diversos cursos al CEFIRE de València i a la Universitat d'Estiu amb seu a Gandia. És membre d'Espai cinema, un grup en xarxa d'innovació educativa que utilitza els audiovisuals com a eina educativa, amb seu a la Facultat de Magisteri de la Universitat de València i colllabora també amb altres activitats a la Facultat de Filosofia i Ciències de l'Educació de la mateix universitat. Pertany a l' ECFA(European Children 's Film Association] amb seu a Brussel.les i a la CIFEJ (Centre Internacional per a les Pel-lícules de la Infermeria i la Jeunesse) amb seu a Teheran. En 2017 va ser nomenat membre de la junta directiva de la CIFEJ (Centre International du Film pour l'Enfance et la Jeunesse]

També és membre de la Xarxa UNIAL. Universo Audiovisual del niño latinoamericano amb seu a l'Havana. Ha treballat com a director d'escena per a obres de teatre i concerts a Espanya i Alemanya. És coautor de tres llibres publicats per la Diputació de Castelló, El Departament d'Educació i l'Ajuntament d'Alzira al voltant d'Educació i ha publicat treballs en diverses revistes especialitzades com Cuadernos de Pedagogia, Revista Futura, Making off, Aularia, Saó i publicacions de la Universitat d'estiu de Gandia.

És president de l'Associació Cultural Jordi el Mussol, director del Festival de Cinema de València per a Xiquets/es, Joves i Mestres Mostra Internacional de Cinema Educatiu (MICE), Assessor d'Artistico expressiu del Servei de Formació del Professorat del CEFIRE de València gestor cultural i productor audiovisual independent.

Actualment és professor assessor en el Centre de Formació, Innovació i Recursos per al Professorat [CEFIRE].

\section{Cóm es presentaria vostè?}

Com a mestre d'escola abans de res. Un mestre nascut a Estivella que ha estat treballant trentacinc anys a escoles d'Educació Primària per mig País i desenvolupant la major part de les seues accions primer a Benetússer i després a València. Un mestre actiu apassionat pel que fa, per l'educació i el cinema i fermament creient de les possibilitats i necessitat de l'audiovisual com a eina didàctica. 


\section{Què es la educomunicació?}

És precisament utilitzar els mitjans de comunicació, com el cinema o els audiovisuals per a educar en qualsevol nivell educatiu i context. Saber utilitzar les imatges per a comunicar i educar i per això és necessari l'empoderament dels mestres que treballen audiovisuals [Arbiol, 2014]. I que a poc a poc es va aconseguint, encara que queda molt de camí per fer.

\section{Que és la Mice?}

La MICE [Mostra Internacional de Cinema Educatiu] és un festival de cinema educatiu. Es va crear fonamentalment amb els objectius de potenciar, difondre i promocionar la cultura audiovisual entre l'alumnat i professorat d'educació primària i secundària, l'intercanvi cultural a nivell estatal i internacional, així com d'integrar als xiquets i xiquetes al món audiovisual. Considere que és molt important per alfabetitzar audiovisualment els estudiants i augmentar la cultura audiovisual per ser més crítics amb ella, dominar els codis mediàtics i alhora poder gaudir més d'ella.

\section{I cóm va sorgir la MICE?}

Havia vist als meus viatges pels festivals d'altres països que donaven molta importància als treballs fets pels estudiants [Arbiol, 2017). Que a nivell educatiu emfatitzaven més l'escriptura que la lectura d'imatges. De la voluntat de posar en valor els treballs audiovisuals que es fan als centre educatius i que es quedaven amagats als calaixos. De les ganes d'oferir una gran pantalla al cinema fet a l'aula. Poc a poc, amb la participació d' estudiants, pares/mares i alguns companys anàrem fent més gran l'audiència i també començarem a contactar amb altres iniciatives semblants en altres part d'Espanya i del món i ens invitaren uns als altres a participar en encontres educatius. Fer xarxa i unir sinèrgies dels francotiradors de l'Educació Audiovisual arreu del món. Després de visitar, per tal de fer una ponència, el Festival BIKY a Busan en Corea del Sud, la gran quantitat d'hores d'avió i aeroports va conformar el primer esborrany del somni en el que es convertiria, més tard, la MICE.

Va començar amb una iniciativa personal meua però de seguida es va sumar més gent i ara formem un equip sòlid de treball, encara que no massa ampli. Encara que pareix que som molts per la quantitat de treball que fem, sols som quatre o cinc persones al llarg de l'any.

\section{Cóm és el present de la MICE?}

El present és que anem ja per la VIl edició! Cada vegada tenim més seus que volen acollir en nostres treballs i collaborar amb nosaltres. Enguany tenim un cartell en el que el prestigiós dissenyador valencià Francis Montesinos que deixat la seua creació amb un fons característic d'ell. Apassionat amb el nou repte i ple d'expectatives. Tenim clar que hem obert un camí on l'escriptura d'imatges és el focus de la mostra i que som un esdeveniment de referència a nivell internacional i cal mantindre la qualitat de la proposta.

\section{Cóm va crear-se l'Associació cultural El Mussol?}

Es va crear aproximadament fa uns set o vuit anys per donar suport als treballs que realitzàvem al colllegi, com a plataforma per ajudar a la difusió dels treballs del alumnes. I també perquè moltes activitats excedien la meua tasca com a funcionari d'educació. Calia buscar un marc legal i així va ser com crearem l'associació. Actualment és la base central de l'organització de la MICE. 


\section{Cóm és capaç d’aglutinar a tantes institucions tan diverses, ajuntaments, col - legis?}

Ha sigut molt de treball, posant molt de positivisme, molta passió i bona voluntat. Molts intents, moltes explicacions i saber que no en totes parts et van a atendre. Fa temps, recorde que igual de deu cridades telefòniques m'atenien una. Al principi costà molt. Això va ser poc a poc i de forma natural quasi tots s'han interessat i volien participar. Conforme la MICE ha anat creixent el "vendre el producte" ha resultat més fàcil. És més, ara són des de diverses institucions i organismes els qui es mostren interessats en forma-hi part. És clar que comporta maldecaps. Coordinar a tants organismes i que tot estiga al gust de tots no és tasca feta. Però sí que està clar que amb ganes es pot realitzar una gran feina unint les diferents sinèrgies i voluntats de treball.

\section{Què és més difícil convèncer a un polític o a un mestre/a?}

Als mestres no he hagut de convèncer-los perquè s'han apropat els que han volgut. En un principi pocs i cada vegada són més els que conformen la xarxa que fa que la MICE siga un èxit. Els polítics també s'impliquen quan veuen que els projectes tenen difusió i van bé, quan tot va bé és fantàstic. El món de la política envers la MICE és igual que de cara a altres esdeveniments. Altra cosa és el tema dels diners...que en els últims temps han sigut molt escassos en comparació al tamany que ha adquirit el festival.

\section{Cóm li agradaria que fóra el futur de la MICE?}

M'agradaria que continuara molts anys més! Encara que no siga jo el que estiga al front perquè la meua idea és deixar la direcció de la MICE enguany. Jo he fet tot el que he pogut però ara necessite descansar un poc. Un futur on es consolide la marca i el camí. Crec que la MICE és un projecte amb molta visibilitat i és higiènic que altre mans i altres idees ajuden a renovar-lo i donar-li més qualitat. Que continuara essent un motor a nivell autonòmic i no perdera les relacions internacionals a les que tant hem aportat i ens han aportat.

\section{Què necessitaria? Cap a on va la MICE?}

Tenim dificultats de finançament i això és un problema greu per a continuar desenvolupant la tasca. Però afortunadament sempre tenim a algú que ens ajuda encara que m'agradaria que les institucions s'implicaren més, ho feren més activament i donaren més suport. Un festival com la MICE allunyat del món de la industria i del consumisme comercial i havent assolit la rellevància que té hauria de passar a mans institucionals si volem que visca més anys i amb aquesta potència. Tal vegada després de les eleccions seria qüestió de seure seriosament amb les administracions adequades per veure la viabilitat d'una possible institucionalització de la mostra.

\section{Quin és el seu treball actualment? Quant de temps li dedica a l'organització de la MICE?}

Treballe com assessor educatiu al CEFIRE de València. Des d'ací organitzem cursos per al professorat i organitzem diverses activitats educatives, dins d'elles hem collaborat molt activament la MICE i també cursos d'educació audiovisual. 


\section{Quin és el seu millor record de la MICE? Amb qui? Cóm?}

Són tants els moments destacats que difícilment podria dir-ne un. Poder conèixer a mites com Marisa Paredes, Agustí Villaronga, Hana Schygulla, José Luís Cuerda, Francesc Betriu. Quan en un sopar, la parella de Marisa Paredes ens contà que havia tingut un "flirteo" amb Lana Turner en Nova York i Marisa li va dir "¿Quieres dejar de hablar de esa?”. També són moments molt agradables quan reps les gràcies de xiquets o xiquetes de tot el món donant les gràcies per poder haver presentat el seu treball. A nivell acadèmic recorde una taula redona a la Universitat Autònoma de Mèxic amb altres directors de festivals de cinema infantil de tot el món. La diferència entre els altres festivals i la MICE era l'origen. Mentre la MICE neix de la base educativa, neix del professorat, tots els altres naixien de la indústria. Com que la majoria d'assistents a la taula redona eren professors el grau d'identificació amb la proposta MICE va ser molt més gran que amb les altres propostes.

\section{I el pitjor?}

Els problemes derivats de les dificultat de finançament, l'estrès, els vint atacs al cor, les cinquanta crisi d'ansietat i les milers de vegades que m'he preguntat "a tu qui te manaria fer açò?" Hi ha moments en que tiraries la tovallola, tancaries els ulls per no vore res o t'amagaries sota un paper de fumar. Però després es passa.

\section{Què ha aprés viatjant arreu del món als festivals?}

Que la gent té moltes ganes de compartir allò que creu és interessant i el seu treball artístic. La forma de fer d'altres festivals ha inspirat molt l'organització de la MICE. Estudiant les formes de fer dels altres i adaptant-les a les nostres característiques i objectius. El principal focus de la MICE és l'educació. A partir d'allò vist en altres indrets hem formulat una proposta adient a les nostres idees $\mathrm{i}$ interessos educatius.

\section{Què coses fem bé ací que podríem exportar?}

Precisament aquest format de Festival, no hi ha cap altre a tota Europa dedicat als estudiants i fet amb treball d'estudiants i que tinga tanta potència i rellevància com la MICE. No és que els altres festivals no tinguen qualitat però des de la MICE ens hem esforçat molt en no ser una secció d'un festival de cine de la indústria, no servir com excusa d'un consumisme inmediatista. El cas és que m'han invitat a molts llocs per a contar l'experiència de la MICE $\mathrm{i}$ ja hi ha festival que continuen plenament el model nostre. També sempre he fet palés del gran treball que es fa a les aules valencianes. Que no cal mirar a Finlàndia en tot moment. Som avantguardistes en el treball audiovisual, encara que, això sí, encara queda un gran camí per fer.

\section{També col - labora amb el grup en xarxa d'innovació educativa de la UV, Espai cinema. Cóm va ser això? Quina és la seua participació?}

Sí, això va ser des de fa uns cinc cursos que van entrar en contacte amb mi per a col·laborar i fer difusió entre els estudiants, especialment entre els mestres en formació dels graus de la Facultat de Magisteri i del Màster en Educació Secundària. He col·laborat amb ells amb la realització de tallers i xarrades en alguna setmana d'activitats complementàries. En general hi ha poca participació universitària a la MICE. Únicament des de l'any passat que hem incorporat a la MICE 
una secció de relats digitals [curtmetratge entre 3 i 5 minuts narrat en primera persona] fets pels estudiants de la menció d'anglès i coordinats per la professora María Alcantud. En aquesta secció un jurat format per professorat membre d’Espai Cinema dóna premis.

\section{Quina és la seua opinió d'altres mestres de primària innovadors que han escrit llibres com César Bona i/altres? No ha pensat en escriure un llibre o Tesis sobre la MICE?}

[Es riu] Bé, està molt bé això d'escriure però no és per a mi, no trobe mai el temps. Si que m'inviten a fer moltes xarrades i això m'agrada però escriure és una altra cosa. En alguna ocasió m'ho han dit, que es podria fer un treball molt bonic i acadèmic amb el tema de la MICE però això jo ho deixe a qui vulga fer-ho. De fet a Mèxic han fet una tesi en la qual s'investiga la MICE i forma part d'una altra a l'Argentina. En aquest sentit sempre ha sigut algú del món universitari que s'ha apropat i m'ha demanat alguna col·laboració, com per exemple Paula Jardón per a unes conferències que després es publicaren [Jardón i Arbiol, 2016] i vaig fer un article en col·laboració sobre la MICE com a cas d'estudi en col·laboració amb un col·lega que es va publicar a una revista de la Universitat Miguel Hernández d’Elx [Alacant] [Arteseros i Arbiol, 2016].

\section{Què diria als lectors de la revista que encara no saben què és la MICE?}

Que s'apropen a la MICE tant si els agrada el cinema com si no, que siguen curiosos perquè sempre podem deixar-se sorprendre, aprendre i descobrir coses noves. I sobretot divertir-se. L'aspecte lúdic de la MICE el treballem minuciosament. Sóc del parer que sense gaudi no hi ha aprenentatge i que la caspa es pot combatre amb un bon i adequat xampú.

\section{Què diria als alumnes de les facultats de Magisteri o Ciències de l'Educació que estan en formació actualment? Cóm les motivaria davant la carència de places d'oposició i els canvis socials?}

Que la vida és molt bonica a pesar de tots els problemes que tenim a l'escola, que quan facin una cosa que s'entreguen i que tiren endavant. Que no esperen que res els vinga donat i que no abandonen a la primera. La generació millennial és cert que té un futur incert o no massa fàcil però que també han tingut oportunitats de formació impensables fa pocs anys.

\section{I de la creativitat i innovació educativa?}

Què les dues són molt necessàries per continuar avançant i aprenent. Crear ha de ser innat al mestre i innovar, a més de trencar la monotonia que fa que fracassen moltes coses a la vida, fa que s'adaptem als temps. La societat canvia. L'educació pot anar al compàs o per davant, però no mai endarrerida amb respectes a les transformacions socials.

\section{Quines són els seus punts forts? I els més dèbils?}

Els punts fort serien que sóc una persona positiva, constant, tenaç, oberta, flexible i creativa. I per altra banda sóc prou desorganitzat, fins i tot caòtic. El que sí he aconseguit amb el temps, l'experiència i els anys és atrevir-me a ser jo mateix, natural, no tinc interès en ser políticament correcte.

\section{Que vol deixar a l'educació i a la societat?}

Una altra forma d'educar amb el cinema o els audiovisuals. I per altra part fer palés de que les 
coses amb constància, tenacitat i treball es poden aconseguir, que res ve donat sense esforç, encara que no mai m’havia plantejat ser un gurú [riu] de res.

\section{Havia pensat alguna vegada que la MICE és un projecte d'innovació no sols educativa sinó social i que vostè és un innovador?}

[Es riu]. Bé, jo no ho havia pensat així, més bé com un mestre que li agrada el cinema i vol ensenyar a fer cinema als seus alumnes perquè amb açò podem aprendre moltes coses i posar en pràctica moltes competències sobretot a nivell escriptura d'imatges. En quant a mi personalment no mai m'havia auto qualificat com d'innovador. La MICE amb el temps sí que s'ha mostrat com un projecte d'innovació i motor de canvis a l'escola en el tema d'escriptura digital.

\section{Cóm li agradaria que recordaren el seu pas per la MICE?}

No ho sé però jo la veritat és que ho he passat molt molt bé! Tal vegada amb estima. Crec que he donat tot el millor que he pogut en aquestes set edicions de la MICE. El temps dirà quan d'encert he tingut o quantes clavades de pota, però el valor i la tenacitat d'haver posat en marxa la mostra és meritori de recordar.

\section{Cóm li agradaria concloure aquest diàleg o entrevista?}

Recordant que és necessari l'empoderament dels mestres. A nivell social el camí i les mirades cap al docent van canviant i positivant-se. També que la MICE començà en una època on València estava als mitjans de comunicació per qüestions de corrupció política i València és molt més, amb la MICE crec que hem donat una visió de la nostra ciutat com a exemple de bones pràctiques a l'Educació, i això ho considere important. Vam posar en aquest aspecte a València al mapa de la innovació.

Moltes gràcies i llarga vida a la MICE! 


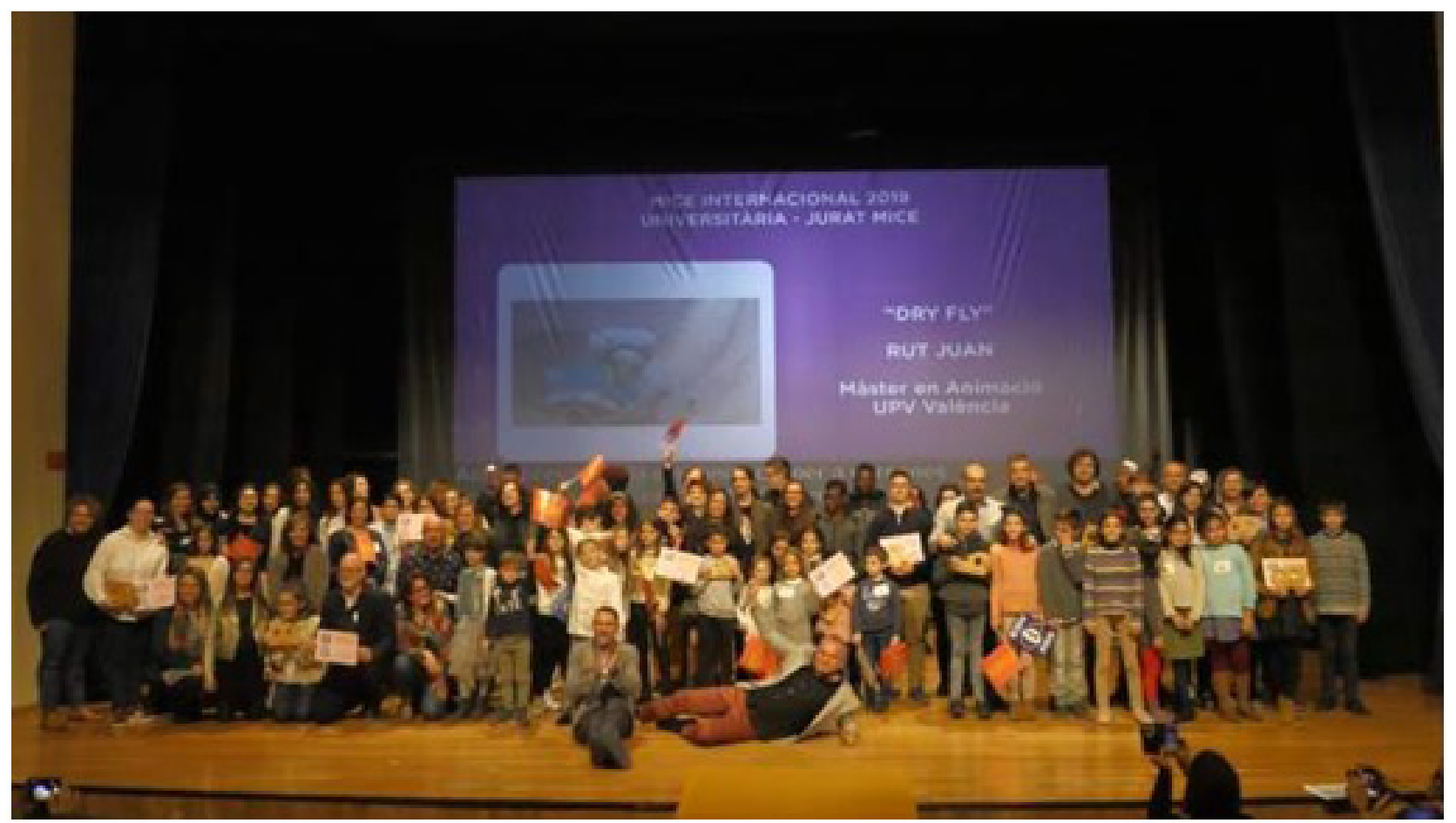

Fig 2. Clausura VII edició de la MICE. Auditori Joaquín Rodrigo, Sagunt (València], 22 de febrer 2019. 


\section{Referències}

Arbiol Carmen, J. [2014]. Un barrio de cine, un cole de película. Cuadernos de Pedagogía, 442, 26-29.

Arbiol Carmen, J. [2017]. ¿Hubo vida antes de la MICE? Making off: cuadernos de cine y educación, 132-133, 72-77.

Arbiol Carmen, J. [2019]. Valencia-España. "Mostra Internacional Cinema Educatiu". Cine y Educación. Aularia: Revista Digital de Comunicación, 8 [2], 53-56.

Arteseros, J. y Arbiol, J. [2016]. La aportación cultural de los festivales de cine: Mostra Internacional de Cinema Educatiu [MICE] como caso de estudio. Miguel Hernández Communication Journal, 7, 443-462. www.mhjournal.org.

Jardón, P. y Arbiol, J. [2016]. El cinema com a eina educativa per al currículum escolar y el treball en xarxa [pp. 173-186]. En V. Pardo Iranzo, Aportacions entorn del desenvolupament territorial i social valencià: conferències 2014 i 2015. Valencia: Universitat de València. Vicerrectorat de Participació i Projecció Territorial.

http://www.micevalencia.com/jordi-el-mussol/

https://www.uv.es/cinemag/ 